\title{
Effect of the Interactive Whiteboard on Vocabulary Achievement, Vocabulary Retention and Learning Attitudes
}

\author{
Truong Minh Hoa
}

Corresponding author, Nguyen Tat Thanh University, Vietnam, ngutngonnguhoc91@gmail.com

Tran Thi Thuy Trang

EPRO Education Product Distribution \& Development Company, Vietnam, trantrang290@ gmail.com

In order to evaluate the success of integrating the Interactive Whiteboard into vocabulary lessons in terms of developing the fifth graders' vocabulary achievement, retention and learning attitudes, the thirteen-week quasi-experimental study was conducted in two classes with the participation of 40 fifth graders as the control group and another 40 from the same grade as the experimental group, respectively. The instruments included three vocabulary tests (e.g. one pre-test, one posttest and one delayed post-test); and the attitude questionnaire. The quantitative data obtained from these measurement tools were analyzed by SPSS. The findings of the study indicated that the Interactive Whiteboard activities positively contributed to the fifth graders' vocabulary achievement and retention of form, meaning and use. Besides, the fifth graders' level of motivation, interest, and active behavioural intentions increased via the Interactive Whiteboard.

Keywords: interactive whiteboard, vocabulary achievement, vocabulary retention, learning attitudes, fifth graders

\section{INTRODUCTION}

Since there is rapid development of technology in the $21^{\text {st }}$ century, Interactive Whiteboard takes prime concern around the world. Inferred from the possibility of improving positive learning attitudes such as motivation, engagement, interest among language learners (Beeland, 2002), it turns out to be an effective instructional device, providing young learners with an active environment to be exposed to the language acquisition. Indeed, mobility, internet connectivity, touchable screen has become salient facets of an Interactive Whiteboard that facilitates young learners' language achievement and enlargement of learning enjoyment (Khoo, Merry, Nguyen, Bennett \& MacMillan, 2014). Taking these merits into account, the Vietnamese government has decided to employ the Interactive Whiteboard to teach English for young learners in the recent years.

In the Vietnamese context, the Interactive Whiteboard was launched as a new tool, but not many provinces exploit it as a medium of language instruction. As declared by Ho Chi Minh City Department of Education and Training, the core educational mission in the period 2016-2020 is to stimulate the concatenation of technology into English language pedagogy. Nevertheless, unlike schools in developed countries where its use has vastly dispersed since the 1990s, this tool has newly appeared in Vietnamese public elementary schools of big cities (e.g. Hanoi, Ho Chi Minh City) since 2014 due to its high cost. Tran Quang Khai primary school (District 1, Ho Chi Minh City, Vietnam) was equipped with an Interactive Whiteboard, haft funded from national budget, and the rest was financed through donation from parents. It is widely known that learning English vocabulary is a vital

Citation: Hoa, T. M., \& Trang, T. T. T. (2020). Effect of the Interactive Whiteboard on Vocabulary Achievement, Vocabulary Retention and Learning Attitudes. Anatolian Journal of Education, 5(2), 173-186. https://doi.org/10.29333/aje.2020.5215a 
section of acquiring a foreign language (Schmitt, 2008). It accomplishes a central constituent of language proficiency to pillar language achievement (Richards \& Renandya, 2002). Yet, vocabulary acquisition involves seeing, hearing and practicing words in lieu of memorizing the word forms only (Daniels \& Zemelman, 2004). According to Mai (2018), one of the technologies that enhance teachers' vocabulary teaching quality and young learners' vocabulary achievement is the Interactive Whiteboard. In fact, young children often love technology and desire to learn with the emergence of digital devices, want to follow their own interests and passions along with experience real things in connection to technology (Prensky, 2010). Hopefully, the Interactive Whiteboard may satisfy their personalities and learning styles.

\section{Problem Statement}

Recently, the demand of acquiring the English language has highly accelerated in the Vietnamese context by dint of its wide presence in various aspects of work and life. By that reason, English was infused into the Vietnamese primary school system as a compulsory subject. However, teaching English to young learners is deemed to be a strenuous task as it requires an array of work and preparations by language teachers. Likewise, teaching and learning English vocabulary at this schooling system in Vietnam embraces a number of unexpected challenges and difficulties which are categorized into two domains, i.e. students' motivation and engagement, and their vocabulary performance.

First, Vietnamese students usually easily get fed up with vocabulary lessons by traditional methods. In a traditional method of teaching, the students are required to copy down words on their notebooks and they mostly rely on teacher's explanation and authority (Nguyen \& Khuat, 2003). Nguyen and Tran (2015) supplement that some of teachers are not creative when delivering vocabulary lessons to young learners. Furthermore, the classroom situation in vocabulary lessons is deemed to be not alive when the teachers perform their supremely dominant roles, which leads to the students' low participation in these lessons. Henceforth, language teachers should use interactive learning tasks and activities to help their students acquire the learnt vocabulary items in meaningful contexts and situations (Nguyen, 2015).

Secondly, as per Luu (2012), for young learners, to consolidate and to retain the vocabulary seems to be difficult. The author also reveals that young learners often express that they keep learning and forgetting. Therefore, when young learners acquire new English vocabulary, they need appropriate methods to collect, and retrieve words for retention and use.

\section{Research Aims and Questions}

Generally speaking, vocabulary classrooms for young learners need to be diverse with instructional materials, activities, and instructional tools, which can heighten young learners' motivation and engagement along with their vocabulary retention and achievement. Predominantly, this study was conducted to check whether the Interactive Whiteboard activities enable the young learners at Tran Quang Khai primary school, Vietnam to have better vocabulary achievement, retain the learnt vocabulary longer and to develop their positive learning attitudes. Accordingly, two research questions were formulated as follows:

1-To what extent does the Interactive Whiteboard enhance the fifth graders' vocabulary achievement and vocabulary retention?

2-What are the fifth graders' attitudes towards the presence of the Interactive Whiteboard in their vocabulary lessons?

\section{METHOD}

\section{Research Design}

To examine the cause-effect relationship between the Interactive Whiteboard (i.e. the independent variable) and the primary school students' vocabulary achievement, retention as well as learning 
attitudes (i.e. the dependent variables), a quasi-experimental design, without random choice of the representative sample (Creswell, 2012), was purposely deployed. In fact, Class 5/1 and Class 5/2 were the control group with conventional way and the experimental group with the Interactive Whiteboard treatment, respectively. This quasi-experimental study consisted of two research hypotheses:

H1: The Interactive Whiteboard has a positive effect on the fifth-grade students' vocabulary achievement, vocabulary retention.

H2: The Interactive Whiteboard has a positive effect on the fifth-grade students' learning attitudes.

\section{Research Setting and Participants}

This study was conducted at Tran Quang Khai primary school, a public primary school situated on 68/29B Tran Quang Khai Street, District 1, Ho Chi Minh City, Vietnam. It was built in December 2008 and commenced the first academic year in September 2009. At present, there are four English teachers responsible for twelve classes. This school has two Interactive Whiteboards. If the teachers want to use the Interactive Whiteboard for language lessons, they have to register every Friday.

Each group had the same number of the participants (40 students). The proportion of gender in both groups was quite similar. The control group comprised 18 males and 22 females, while the experimental group consisted of 19 males and 21 females. In addition, nearly all the students were 11 years old (98.75\%). Positively, more than $90 \%$ of the sample liked to learn English (91.25\%). Apart from the academic course at the primary school, beyond three quarters of the participants also took up other English courses (76.25\%).

\section{Material}

The students of both groups used the textbook namely "Family and Friends Special Edition 5" published by Oxford University Press, including one Student Book and one Work Book. The Student Book consists of 12 units, each of which includes various sections such as language knowledge (vocabulary, grammar, and phonetics), and language skills (reading, listening, speaking and writing skills). In this research, five units numbered 8-12 of the second semester of the academic year 20182019 were chosen. The content of these units taught includes identifying different food items (Unit 8), identifying and describing different places (Unit 9), identifying different objects in the park (Unit 10), identifying different types of transportation (Unit 11), describing characteristics of people (Unit 12).

\section{Time Distribution}

The quasi-experimental study was carried out in the total 13 weeks from February to May, 2019 (see Table 1 below).

Table 1

Time Distribution of the Experiment

\begin{tabular}{|c|c|c|c|c|}
\hline Week & Date & Content & Experimental & Control \\
\hline 1 & February $11^{\text {th }}-$ February $16^{\text {th }} 2019$ & \multicolumn{3}{|c|}{ Distributing the pre-test to both groups } \\
\hline 1 & February $11^{\text {th }}-$ February $16^{\text {th }} 2019$ & Running Unit 8 & & \multirow{10}{*}{ 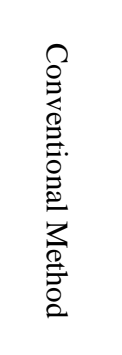 } \\
\hline 2 & February $18^{\text {th }}-$ February $23^{\text {th }} 2019$ & Running Unit 8 & & \\
\hline 3 & February $25^{\text {th }}-$ March $2^{\text {nd }} 2019$ & Running Unit 9 & & \\
\hline 4 & March $4^{\text {th }}-$ March $9^{\text {th }} 2019$ & Running Unit 9 & $\exists \stackrel{\Xi}{2}$ & \\
\hline 5 & March $11^{\text {th }}-$ March $16^{\text {th }} 2019$ & Running Unit 10 & $\exists<0$ & \\
\hline 6 & March $18^{\text {th }}-$ March $23^{\text {rd }} 2019$ & Running Unit 10 & 气ొ ْి & \\
\hline 7 & March $25^{\text {th }}-$ March $30^{\text {th }} 2019$ & Running Unit 11 & $\bar{g} \bar{\Xi} \overline{0}$. & \\
\hline 8 & April $1^{\text {st }}-$ April $6^{\text {th }} 2019$ & Running Unit 11 & & \\
\hline 9 & April $8^{\text {th }}-$ April $13^{\text {th }} 2019$ & Running Unit 12 & $<$ & \\
\hline 10 & April $15^{\text {th }}-$ April $20^{\text {th }} 2019$ & Running Unit 12 & & \\
\hline 10 & Anril $15^{\text {th }}-$ Anril $20^{\text {th }} 2019$ & \multirow{2}{*}{\multicolumn{3}{|c|}{$\begin{array}{l}\text { Distributing the post-test to both groups } \\
\text { Delivering the questionnaire to the experimental group }\end{array}$}} \\
\hline & & & & \\
\hline 13 & May $6^{\text {th }}-$ May $11^{\text {th }} 2019$ & \multicolumn{3}{|c|}{ Distributing the delayed post-test to both groups } \\
\hline
\end{tabular}




\section{Lesson Plans for the Control and Experimental Groups}

To the experimental group and the control group, each vocabulary lesson was taught based on five consecutive stages, inclusive of Warm-up, Presentation, Practice, Production and Review. However, there were some differences and similarities in delivering vocabulary lessons to two groups.

In Warm-up stage, the researchers used same activities for both groups. For example, the researchers employed the game named Simon says for both groups before teaching new words (Unit 8). In Unit 9, the researchers asked the experimental group to sing a song, while the control group was delivered flashcards. In Unit 10, the experimental group did some mimes, while the control group was still exposed to the flashcards. In Unit 11, the researchers also asked the experimental group to sing a song, while the control group was asked to work on flashcards. In Unit 12, both groups were energized with flashcards provided by the researchers.

In Presentation stage, the researchers let the experimental group notice forms, meanings and use of the new vocabulary by video clips and flashcards on the Interactive Whiteboard screen. Meanwhile, the control group was introduced new vocabulary by looking at the pictures in their textbook and repeating the recording several times in chorus.

In Practice stage, the experimental group was provided controlled practice activities in which the students had opportunities to manipulate operations of the Interactive Whiteboard such as Drag and Drop, Hide and Reveal, and Color and Highlight. The controlled practice activities were Spotting the Errors, Matching Spelling and Sound (Bingo), Labeling Pictures and Ordering the Jumbled Sentences. By contrast, the researchers used intact vocabulary exercises in the Family and Friends Grade 5 for the control group.

In Production stage, the experimental group was provided free activities in which the students had opportunities to manipulate functions of the Interactive Whiteboard such as Drag and Drop, Hide and Reveal, and Color and Highlight. The controlled practice activities were Word Association, Ordering the Jumbled Sentences, and Free Writing. The experimental group was required to work collaboratively with the classmates. On the contrary, the researchers only used vocabulary exercises available in the Family and Friends Grade 5 for the control group.

In Review stage, the researchers applied the same activities for both groups in helping them review the newly learnt vocabulary items in the previous period. These review activities involved using worksheets or flashcards.

\section{Instruments: Description, Collection and Analysis \\ Vocabulary Tests}

Functionally, in the first week, the vocabulary pre-test was administered to the experimental and control groups to attest any incongruity between two groups before the Interactive Whiteboard treatment, which could affect the genuine results of this target treatment. In the tenth week, the vocabulary post-test was conducted to both groups with the purpose of testifying if the treatment made any progress in vocabulary achievement by the experimental group. In the thirteenth week, two groups received another post-test (i.e. the delayed post-test) to check their vocabulary retention level for one two-week period.

Structurally, the vocabulary pre-test, post-test, and delayed post-test shared the same format in regard to the number of items, test types, and scoring rubrics. Firstly, each of them consisted of 20 items in total. Secondly, each of the vocabulary tests included four test types: Matching, deciding True or False, filling in the blank, and reordering. These four test types were based on Circular No. 22 issued by the Vietnamese MOET in 2016 about language assessment for the primary school students. So as to avoid the memory effect about the answer, the order of items and sections in the delayed post-test, compared to the post-test, was changed. Thirdly, the scoring rubric was clear and stable, in which one 
correct answer obtained 0.5 point, and the maximum score achieved 10.0 points. Noticeably, the content and vocabulary used for these tests were congruent with whatever they had acquired in the previous lessons, and with the fifth graders' current language ability.

Analytically, Statistical Package for the Social Sciences (SPSS) was used, and independent samples ttest was run to measure the statistical differences in mean scores of the pre-test, the post-test and the delayed post-test between two groups. Besides, paired samples t-test was run to measure the differences in the mean scores between the pre-test, the post-test and the delayed post-test within two groups.

\section{Attitude Questionnaire}

Functionally, to investigate the effect of the Interactive Whiteboard on the fifth-grade students' learning attitudes (e.g. emotions, beliefs and behaviors), a questionnaire, which is a numerical data collection technique in educational research (Creswell, 2012) and one of the most useful tools to exploit subjects' attitudes, beliefs and perceptions (Koshy, 2005), was delivered to the experimental group. Structurally, the reliable 14-item questionnaire, with the Cronbach's Alpha values $(=0.847)$ greater than 0.700 (Pallant, 2005), consisted of three discrete sections: affective (Items AA1-5), cognitive (Items CA1-5) and behavioral attitudes (Items BA11-14). These items were rated on a fivepoint Likert-scale, including 1: strongly disagree, 2: disagree, 3: uncertain, 4: agree, and 5: strongly agree, supporting the researchers to measure opinions and attitudes quantitatively (Cohen, Manion \& Morrison, 2011). Analytically, SPSS 22.0 was also used to yield the descriptive statistics of the questionnaire in terms of percentage (P, \%), mean $(\mathrm{M})$ and standard deviation (S.D.).

\section{FINDINGS}

\section{Vocabulary Tests}

Table 2

Group Statistics on the Pre-test of the Control and Experimental Groups

\begin{tabular}{llccccc}
\hline \multicolumn{7}{c}{ Group Statistics } \\
\hline & $\mathrm{N}$ & Mean & Std. Deviation & Min. & Max. \\
\hline Pre- & Control group & 40 & 5.65 & 1.210 & 4.0 & 8.0 \\
test & Experimental group & 40 & 5.48 & 1.240 & 3.5 & 8.0 \\
\hline
\end{tabular}

Table 3

Independent Samples T-test on the Pre-test of the Control and Experimental Groups

\begin{tabular}{|c|c|c|c|c|c|c|c|c|c|}
\hline \multicolumn{10}{|c|}{ Independent Samples T-test } \\
\hline & \multicolumn{2}{|c|}{$\begin{array}{l}\text { Levene's Test } \\
\text { for Equality } \\
\text { of Variances }\end{array}$} & \multicolumn{7}{|c|}{ T-test for Equality of Means } \\
\hline & \multirow[t]{2}{*}{$\mathrm{F}$} & \multirow[t]{2}{*}{ Sig. } & \multirow[t]{2}{*}{$\mathrm{t}$} & \multirow[t]{2}{*}{ df } & \multirow{2}{*}{$\begin{array}{l}\text { Sig. (2- } \\
\text { tailed) }\end{array}$} & \multirow{2}{*}{$\begin{array}{l}\text { Mean } \\
\text { Difference }\end{array}$} & \multirow{2}{*}{$\begin{array}{l}\text { Std. Error } \\
\text { Difference }\end{array}$} & \multicolumn{2}{|c|}{$\begin{array}{l}\text { 95\% Confidence Interval o } \\
\text { the Difference }\end{array}$} \\
\hline & & & & & & & & Lower & Upper \\
\hline $\begin{array}{l}\text { Equal variances } \\
\text { assumed }\end{array}$ & .060 & .807 & -.639 & 78 & .525 & -.175 & .274 & -.720 & .370 \\
\hline $\begin{array}{l}\text { Equal variances } \\
\text { not assumed }\end{array}$ & & & -.639 & 77.953 & .525 & -.175 & .274 & -.720 & .370 \\
\hline
\end{tabular}

As illustrated in Table 2, the mean score produced by the control group was rather higher than the mean score of the experimental group, with 5.65 (S.D.=1.210) and 5.48 (S.D.=1.240), respectively. More specific, the variation of the pre-test scores in the control group was from 4.0 to 8.0, while that in the experimental group was 3.5 to 8.0. Yet, the data from Table 3 below indicated that the mean score of the control group was only higher than the mean score of the experimental group with 0.175. This difference was not statistically significant when the Sig. (2-tailed) value of .525 was greater than the alpha value of .050 . Especially, The F value for Levene's test was .060 with p value of $.807>.050$, indicating that there was no statistically significant difference between the two group's variances. 
Hence, it might be concluded that both groups shared the similarity of vocabulary background prior to the treatment. This was seen as a comfortable condition for the researchers to judge the effectiveness of the Interactive Whiteboard activities on vocabulary lessons exactly.

After ten weeks of the treatment, the researchers delivered the post-test to the both groups to examine their progress after a given period of time. Paired samples t-tests were run on the pre-test and the posttest within groups.

Table 4

Paired Samples Statistics in the Pre-Test and the Post-Test of the Control Group

Paired Samples Statistics

\begin{tabular}{lllllll}
\hline \multicolumn{2}{l}{ Control group } & $\mathrm{N}$ & Mean & Std. Deviation & Min. & Max. \\
\hline Pair & Pre-test - & 40 & 5.65 & 1.210 & 4.0 & 8.0 \\
1 & Post-test & 40 & 5.88 & 1.223 & 4.0 & 8.0 \\
\hline
\end{tabular}

Table 5

Results of Paired Samples T-test in the Pre-test and the Post-test of the Control Group

Paired Samples Test

\begin{tabular}{|c|c|c|c|c|c|c|c|c|}
\hline \multirow[b]{2}{*}{ Control group } & \multicolumn{5}{|c|}{ Paired Differences } & \multirow[b]{2}{*}{$\mathrm{t}$} & \multirow[b]{2}{*}{$\mathrm{df}$} & \multirow[b]{2}{*}{$\begin{array}{l}\text { Sig. (2- } \\
\text { tailed) }\end{array}$} \\
\hline & $\begin{array}{l}\text { Mean } \\
\text { Difference }\end{array}$ & $\begin{array}{l}\text { Std. } \\
\text { Deviation }\end{array}$ & $\begin{array}{l}\text { Std. Error } \\
\text { Mean }\end{array}$ & $\begin{array}{l}95 \% \mathrm{C} \\
\text { Lower }\end{array}$ & $\begin{array}{l}\text { Interval of the Difference } \\
\text { Upper }\end{array}$ & & & \\
\hline $\begin{array}{ll}\text { Pair } 1 & \text { Pre-test }- \\
\text { Post-test }\end{array}$ & -.225 & 1.165 & .184 & -.598 & .148 & -1.221 & 39 & .229 \\
\hline
\end{tabular}

As shown in Table 4, being experienced to the conventional approach, the control group did make progress in their vocabulary achievement after the whole study. Evidently, within this group, the mean score of the post-test increased from $M=5.65$ (S.D.=1.210) to $M=5.88$ (S.D.=1.223). However, the score range was still unchanged, with Min.=4.0 and Max.=8.0. In addition, no statistically significant difference was sought because from Table 5, the Sig. (2-tailed) value was higher than the alpha value, .229 compared with .050 . Nevertheless, we should highly appreciate the control group's efforts for their vocabulary test performance.

Table 6

Paired Samples Statistics in the Pre-Test and the Post-Test of the Experimental Group Paired Samples Statistics

\begin{tabular}{|c|c|c|c|c|c|c|}
\hline \multicolumn{2}{|c|}{ Experimental group } & $\mathrm{N}$ & Mean & Std. Deviation & Min. & Max. \\
\hline Pair & Pre-test & 40 & 5.48 & 1.240 & 3.5 & 8.0 \\
\hline 2 & Post-test & 40 & 6.25 & 1.235 & 4.0 & 8.5 \\
\hline
\end{tabular}

Table 7

Results of Paired Samples T-test in the Pre-test and the Post-test of the Experimental Group

\begin{tabular}{|c|c|c|c|c|c|c|c|c|}
\hline \multicolumn{9}{|l|}{ Paired Samples Test } \\
\hline \multirow[b]{2}{*}{ Experimental group } & \multicolumn{5}{|c|}{ Paired Differences } & \multirow[b]{2}{*}{$\mathrm{t}$} & \multirow[b]{2}{*}{ df } & \multirow[b]{2}{*}{$\begin{array}{l}\text { Sig. (2- } \\
\text { tailed) }\end{array}$} \\
\hline & $\begin{array}{l}\text { Mean } \\
\text { Difference }\end{array}$ & $\begin{array}{l}\text { Std. } \\
\text { Deviation }\end{array}$ & $\begin{array}{l}\text { Std. } \\
\text { Error } \\
\text { Mean }\end{array}$ & $\begin{array}{l}95 \% \text { Confi } \\
\text { Difference } \\
\text { Lower }\end{array}$ & $\begin{array}{l}\text { Interval of the } \\
\text { Upper }\end{array}$ & & & \\
\hline $\begin{array}{ll}\text { Pair } 2 & \text { Pre-test - } \\
\text { Post-test }\end{array}$ & -.775 & 1.476 & .233 & -1.247 & -.303 & -3.321 & 39 & .002 \\
\hline
\end{tabular}

Unlike the control group, a statistically significant difference was found in the experimental group when the researchers made a comparison between the pre-test and the post-test results. Indeed, Table 7 shows that the Sig. (2-tailed) value of .002 was much less than the alpha value of .050. Statistically, as Table 6 reveals, the experimental group achieved 6.25 (S.D.=1.235) for their mean score, while at the outset of the study, the mean score of the pre-test was only 5.48 (S.D.=1.210). Additionally, the range of the test scores also positively changed; in specific, Min. $=3.5$ and Max. $=8.0$ on the pre-test, and Min.=4.0 and Max.=8.5 on the post-test. To conclude, the experimental group considerably upgraded 
their vocabulary achievement after ten weeks of the treatment. In other words, the Interactive Whiteboard greatly contributed to the fifth-grade students' vocabulary learning.

Table 8

Group Statistics on the Post-test of the Control and Experimental Groups

\begin{tabular}{|c|c|c|c|c|c|}
\hline \multicolumn{6}{|l|}{ Group Statistics } \\
\hline & $\mathrm{N}$ & Mean & Std. Deviation & Min. & Max. \\
\hline Post Control group & 40 & 5.88 & 1.235 & 4.0 & 8.0 \\
\hline -test Experimental group & 40 & 6.25 & 1.223 & 4.0 & 8.5 \\
\hline
\end{tabular}

Table 9

Independent Samples T-test on the Post-test of the Control and Experimental Groups

\begin{tabular}{|c|c|c|c|c|c|c|c|c|c|}
\hline \multicolumn{10}{|c|}{ Independent Samples T-test } \\
\hline & \multicolumn{2}{|c|}{$\begin{array}{l}\text { Levene's Test for } \\
\text { Equality of } \\
\text { Variances }\end{array}$} & \multicolumn{7}{|c|}{ T-test for Equality of Means } \\
\hline & \multirow[t]{2}{*}{$\mathrm{F}$} & \multirow[t]{2}{*}{ Sig. } & \multirow[t]{2}{*}{$\mathrm{t}$} & \multirow[t]{2}{*}{ df } & \multirow{2}{*}{$\begin{array}{l}\text { Sig. (2- } \\
\text { tailed) }\end{array}$} & \multirow{2}{*}{$\begin{array}{l}\text { Mean } \\
\text { Difference }\end{array}$} & \multirow{2}{*}{$\begin{array}{l}\text { Std. Error } \\
\text { Difference }\end{array}$} & \multicolumn{2}{|c|}{$\begin{array}{l}95 \% \text { Confidence Interval } \\
\text { of the Difference }\end{array}$} \\
\hline & & & & & & & & Lower & Upper \\
\hline $\begin{array}{l}\text { Equal variances } \\
\text { assumed }\end{array}$ & .464 & .498 & 1.364 & 78 & .176 & .375 & .275 & -.172 & .922 \\
\hline $\begin{array}{l}\text { Equal variances } \\
\text { not assumed }\end{array}$ & & & 1.364 & 77.993 & .176 & .375 & .275 & -.172 & .922 \\
\hline
\end{tabular}

An independent samples t-test was run on the post-test results to ascertain the significant difference in vocabulary achievement between the two groups after ten weeks. As shown in Table 8, no statistically significant difference was recognized because the Sig. (2-tailed) value was higher than the alpha value, .176 compared with .050. Conspicuously, Table 9 discloses that the score ranges of the post-test performed by the two groups were not much different; for example, Min.=4.0 and Max.=8.0 in the control group, and Min.=4.0 and Max.=8.5 in the experimental group. It means that both groups made progress in vocabulary achievement after the treatment regardless of the extent.

After two weeks since the post-test administration, the researchers sent the delayed post-test to the both groups to examine their vocabulary retention over the time. Paired samples t-tests were run on the post-test and the delayed post-test within groups.

Table 10

Paired Samples Statistics in the Post-Test and the Delayed Post-Test of the Control Group

\begin{tabular}{ccccccc}
\hline \multicolumn{8}{c}{ Paired Samples Statistics } \\
\hline \multirow{2}{*}{ Pair 3} & Control group & Pean & Std. Deviation & Min. & Max. \\
\cline { 3 - 7 } & \multirow{2}{*}{ Post-test - Delayed Post-test } & 40 & 5.88 & 1.223 & 4.0 & 8.0 \\
& 40 & 6.25 & 1.104 & 4.0 & 8.5 \\
\hline
\end{tabular}

Table 11

Results of Paired Samples T-test in the Post-Test and the Delayed Post-Test of the Control Group Paired Samples Test

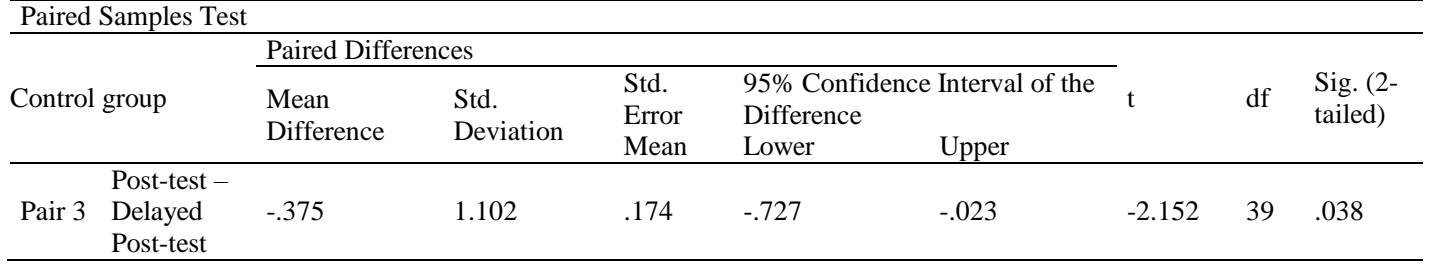

The data of Table 10 elucidates that the mean score of the delayed post-test was much bigger than that of the post-test, with $\mathrm{M}=6.25$ (S.D.=1.104) and $\mathrm{M}=5.88$ (S.D.=1.223), respectively. Yet, the range of test scores in the delayed post-test nearly kept the same as that in the post-test. In addition, Table 11 
reveals that the difference in mean scores was statistically significant as the Sig. (2-tailed) value was .038 , less than the alpha value of .050 . It is inferred from after the period of two weeks, the control group still memorized the vocabulary items well.

Table 12

Paired Samples Statistics in the Post-Test and the Delayed Post-Test of the Experimental Group

\begin{tabular}{ccccccc}
\hline \multicolumn{7}{c}{ Paired Samples Statistics } \\
\hline \multirow{2}{*}{ Eair 4 4} & N & Mean & Std. Deviation & Min. & Max. \\
& \multirow{2}{*}{ Post-test - Delayed Post-test } & 40 & 6.25 & 1.235 & 4.0 & 8.5 \\
& & 40 & 6.80 & 1.137 & 5.0 & 9.0 \\
\hline
\end{tabular}

Table 13

Results of Paired Samples T-test in the Post-Test and the Delayed Post-Test of the Experimental Group

\begin{tabular}{|c|c|c|c|c|c|c|c|c|c|}
\hline \multicolumn{10}{|c|}{ Paired Samples Test } \\
\hline \multirow{2}{*}{\multicolumn{2}{|c|}{ Experimental group }} & \multicolumn{5}{|c|}{ Paired Differences } & \multirow[b]{2}{*}{$\mathrm{t}$} & \multirow[b]{2}{*}{ df } & \multirow[b]{2}{*}{$\begin{array}{l}\text { Sig. (2- } \\
\text { tailed) }\end{array}$} \\
\hline & & $\begin{array}{l}\text { Mean } \\
\text { Difference }\end{array}$ & $\begin{array}{l}\text { Std. } \\
\text { Deviation }\end{array}$ & $\begin{array}{l}\text { Std. } \\
\text { Error } \\
\text { Mean }\end{array}$ & $\begin{array}{l}95 \% \text { Confi } \\
\text { Difference } \\
\text { Lower }\end{array}$ & $\begin{array}{l}\text { Interval of the } \\
\text { Unper }\end{array}$ & & & \\
\hline Pair 4 & $\begin{array}{l}\text { Post-test - } \\
\text { Delayed } \\
\text { Post-test }\end{array}$ & -.550 & .876 & .138 & -.830 & -.270 & -3.973 & 39 & .000 \\
\hline
\end{tabular}

Similar to the control group, the experimental group also performed the delayed post-test more successfully, compared to the post-test. Numerically, as Table 12 described, the mean score of the delayed post-test was 6.80 (S.D.=1.137) and that of the post-test was 6.25 (S.D.=1.235). The score range also showed its more variability; for instance, Min. $=4.0$ and Max. $=8.5$ on the post-test, and Min.=5.0 and Max.=9.0 on the delayed post-test. As shown in Table 13, there was a statistically significant difference in mean score between the delayed post-test and the post-test when the Sig. (2tailed) value was .000 , less than the alpha value of .050. In other words, after two delayed weeks, the students belonging to the experimental group still memorized the words well. That is to say, the Interactive Whiteboard could help the young students retain the learnt words for a given period of time.

Table 14

Group Statistics on the Delayed Post-test of the Control and Experimental Groups

\begin{tabular}{llccccc}
\hline \multicolumn{7}{c}{ Group Statistics } \\
\hline & $\mathrm{N}$ & Mean & Std. Deviation & Min. & Max. \\
\hline Delayed & Control group & 40 & 40 & 6.25 & 1.104 & 4.0 \\
Post-test & Experimental group & 40 & 40 & 6.80 & 1.137 & 5.0 \\
\hline
\end{tabular}

Table 15

Independent Samples T-test on the Delayed Post-test of the Control and Experimental Groups

\begin{tabular}{|c|c|c|c|c|c|c|c|c|c|}
\hline \multicolumn{10}{|c|}{ Independent Samples T-test } \\
\hline & \multicolumn{2}{|c|}{$\begin{array}{l}\text { Levene's Test } \\
\text { for Equality } \\
\text { of Variances }\end{array}$} & \multicolumn{7}{|c|}{ T-test for Equality of Means } \\
\hline & \multirow[t]{2}{*}{$\mathrm{F}$} & \multirow[t]{2}{*}{ Sig. } & \multirow[t]{2}{*}{$\mathrm{t}$} & \multirow[t]{2}{*}{$\mathrm{df}$} & \multirow[t]{2}{*}{$\begin{array}{l}\text { Sig. (2- } \\
\text { tailed) }\end{array}$} & \multirow[t]{2}{*}{$\begin{array}{l}\text { Mean } \\
\text { Difference }\end{array}$} & \multirow[t]{2}{*}{$\begin{array}{l}\text { Std. Error } \\
\text { Difference }\end{array}$} & \multicolumn{2}{|c|}{$\begin{array}{l}95 \% \text { Confidence } \\
\text { Interval of the } \\
\text { Difference }\end{array}$} \\
\hline & & & & & & & & Lower & Upper \\
\hline $\begin{array}{l}\text { Equal variances } \\
\text { assumed }\end{array}$ & .212 & .647 & 2.196 & 78 & .031 & .550 & .251 & .051 & 1.049 \\
\hline $\begin{array}{l}\text { Equal variances } \\
\text { not assumed }\end{array}$ & & & 2.196 & 77.932 & .031 & .550 & .251 & .051 & 1.049 \\
\hline
\end{tabular}


As can be seen from Table 14, the experimental group outperformed the control group in the delayed post-test, with $\mathrm{M}=6.80$ (S.D.=1.104) and $\mathrm{M}=6.25$ (S.D.=1.137), respectively. This disparity also was reflected in the score range, in which the scores of the experimental group scattered from 5.0 to 9.0 while those of the control group distributed from 4.0 to 8.5. Table 15 also claims that there was a statistically significant difference on the delayed post-test between two groups, proven by the Sig. (2tailed) value of .031 higher than the alpha value of .050 . Overall, although both groups recollected the learnt vocabulary items well, the experimental group seemed to memorize better than the other group.

\section{Attitude Questionnaire}

Table 16

The Students' Affective Attitudes

\begin{tabular}{|c|c|c|c|c|c|c|c|c|c|}
\hline Item & Statement & & SD* & $\mathrm{D}^{*}$ & $\mathrm{U}^{*}$ & $\mathrm{~A}^{*}$ & $\mathrm{SA}^{*}$ & M & S.D. \\
\hline AA1 & $\begin{array}{l}\text { I like manipulating functions of the } \\
\text { Interactive Whiteboard. }\end{array}$ & $\begin{array}{l}\mathrm{P} \\
(\%)\end{array}$ & 0.0 & 0.0 & 0.0 & 30.0 & 70.0 & 4.70 & 0.464 \\
\hline AA2 & $\begin{array}{l}\text { I like learning vocabulary with the } \\
\text { Interactive Whiteboard. }\end{array}$ & $\begin{array}{l}\mathrm{P} \\
(\%)\end{array}$ & 0.0 & 2.5 & 2.5 & 50.0 & 45.0 & 4.38 & 0.667 \\
\hline AA3 & $\begin{array}{l}\text { I find my vocabulary lessons } \\
\text { mediated by the Interactive } \\
\text { Whiteboard interesting. }\end{array}$ & $\begin{array}{l}\mathrm{P} \\
(\%)\end{array}$ & 2.5 & 2.5 & 12.5 & 45.0 & 37.5 & 4.13 & 0.911 \\
\hline AA4 & $\begin{array}{l}\text { The Interactive Whiteboard motivates } \\
\text { me to learn vocabulary. }\end{array}$ & $\begin{array}{l}\mathrm{P} \\
(\%)\end{array}$ & 0.0 & 5.0 & 7.5 & 37.5 & 50.0 & 4.33 & 0.829 \\
\hline AA5 & $\begin{array}{l}\text { I find a difference between my } \\
\text { teacher's use of a blackboard and the } \\
\text { Interactive Whiteboard. }\end{array}$ & $\begin{array}{l}\mathrm{P} \\
(\%)\end{array}$ & 5.0 & 7.5 & 20.0 & 30.0 & 37.5 & 3.88 & 1.159 \\
\hline
\end{tabular}

(*) SD: Strongly disagree, D: Disagree, U: Uncertain, A: Agree, SA: Strongly agree

As illustrated in Table 16, the fifth-grade students disclosed their positive affective attitudes towards learning vocabulary with the Interactive Whiteboard. Most strikingly, the descriptive statistics show that all the participants were favoured of manipulating functions of the Interactive Whiteboard (Item AA1, 30.0\% agree, 70.0\% strongly agree, M=4.70, S.D.=0.464). Positively, nearly all the participants (Item AA2, 50.0\% agree, $45.0 \%$ strongly agree, $\mathrm{M}=4.38$, S.D.=0.667) expressed their high preference on learning vocabulary with this technology tool. To elaborate, the majority of the participants felt motivated when learning vocabulary with it (Item AA4, 37.5\% agree, 50.0\% strongly agree, $\mathrm{M}=4.33$, S.D.=0.829). In addition, a large number of the respondents also found the Interactive Whiteboardbased vocabulary lessons interesting (Item AA3, 45.0\% agree, 37.5\% strongly agree, M=4.13, S.D.=0.911). Ultimately, with Item AA5, more than two-thirds of the experimental group felt that learning vocabulary with the Interactive Whiteboard was different from that with the blackboard (30.0\% agree, $37.5 \%$ strongly agree, $M=3.88$, S.D.=1.159).

Table 17

The Students' Cognitive Attitudes

\begin{tabular}{|c|c|c|c|c|c|c|c|c|c|c|}
\hline Item & Statement & & $\mathrm{SD}^{*}$ & $\mathrm{D}^{*}$ & $\mathrm{U}^{*}$ & $\mathrm{~A}^{*}$ & & $\mathrm{SA}^{*}$ & M & S.D \\
\hline CA6 & $\begin{array}{l}\text { I find that the Interactive Whiteboard is useful } \\
\text { to my vocabulary learning. }\end{array}$ & $\begin{array}{l}\mathrm{P} \\
(\%)\end{array}$ & 0.0 & 0.0 & 5.0 & 25.0 & 70.0 & 4.65 & & 0.580 \\
\hline CA7 & $\begin{array}{l}\text { I can understand the meaning of new words } \\
\text { better with the Interactive Whiteboard. }\end{array}$ & $\begin{array}{l}\mathrm{P} \\
(\%)\end{array}$ & 5.0 & 2.5 & 7.5 & 42.5 & 42.5 & 4.15 & & 1.027 \\
\hline CA8 & $\begin{array}{l}\text { I can memorize the form of new words better } \\
\text { with the Interactive Whiteboard. }\end{array}$ & $\begin{array}{l}\mathrm{P} \\
(\%)\end{array}$ & 0.0 & 5.0 & 7.5 & 37.5 & 50.0 & 4.33 & & 0.829 \\
\hline CA9 & $\begin{array}{l}\text { I can understand the use of new words more } \\
\text { clearly with the Interactive Whiteboard. }\end{array}$ & $\begin{array}{l}\mathrm{P} \\
(\%)\end{array}$ & 5.0 & 5.0 & 12.5 & 40.0 & 37.5 & 4.00 & & 1.086 \\
\hline CA10 & $\begin{array}{l}\text { I can pronounce new words more correctly } \\
\text { with the Interactive Whiteboard. }\end{array}$ & $\begin{array}{l}\mathrm{P} \\
(\%)\end{array}$ & 0.0 & 2.5 & 2.5 & 45.0 & 50.0 & 4.43 & & 0.656 \\
\hline
\end{tabular}

(*) SD: Strongly disagree, D: Disagree, U: Uncertain, A: Agree, SA: Strongly agree 
Overall, as Table 17 illustrates, the students divulged their positive cognitive attitudes towards or strong beliefs on the effects of the Interactive Whiteboard on the primary school students' vocabulary achievement and vocabulary retention. Indeed, by the highest mean value, the Interactive Whiteboard was strongly believed to be useful for almost all the students' vocabulary learning (Item CA6, 25.0\% agree, $70.0 \%$ strongly agree, $\mathrm{M}=4.65$, S.D. $=0.580$ ). The other items of this attitudinal group (e.g. Item CA7, Item CA8, Item CA9, and Item CA10) were employed to elucidate this acknowledged usefulness of the Interactive Whiteboard to the students' vocabulary performance. First, $95.0 \%$ of the participants believed that their vocabulary pronunciation was more correct when they were exposed to the Interactive Whiteboard during the vocabulary lessons (Item CA10, $45.0 \%$ agree, 50.0\% strongly agree, $\mathrm{M}=4.43$, S.D. $=0.656$ ). Secondly, with Item CA8, nearly four-fifths of the respondents thought that they could memorize the newly learnt vocabulary forms better $(37.5 \%$ agree, $50.0 \%$ strongly agree, $M=4.33$, S.D.=0.829). Thirdly, beyond four-fifths of the informants considered that the Interactive Whiteboard also contributed to their clear understanding of the vocabulary meanings (Item CA7, $42.5 \%$ agree, $42.5 \%$ strongly agree, $M=4.15$, S.D.=1.027). Apart from the good effects of the Interactive Whiteboard on the students' pronunciation, forms and meanings, this technology tool also made many of them grasp the word use better, acquiesced by $77.5 \%$ of the students (Item CA9, $40.0 \%$ agree, $37.5 \%$ strongly agree, $\mathrm{M}=4.00$, S.D. $=1.086$ ).

Table 18

The Students' Behavioral Attitudes

\begin{tabular}{|c|c|c|c|c|c|c|c|c|c|}
\hline Item & Statement & & $\mathrm{SD}^{*}$ & $\mathrm{D}^{*}$ & $\mathrm{U}^{*}$ & $\mathrm{~A}^{*}$ & SA* & M & S.D. \\
\hline BA11 & $\begin{array}{l}\text { I want to participate collectively in vocabulary } \\
\text { lessons with the Interactive Whiteboard. }\end{array}$ & $\begin{array}{l}\mathrm{P} \\
(\%)\end{array}$ & 7.5 & 7.5 & 0.0 & 30.0 & 55.0 & 4.18 & 1.238 \\
\hline BA12 & $\begin{array}{l}\text { I want to practice vocabulary tasks much more } \\
\text { with the Interactive Whiteboard. }\end{array}$ & P & 5.0 & 7.5 & 12.5 & 37.5 & 37.5 & 3.95 & 1.131 \\
\hline BA13 & $\begin{array}{l}\text { I concentrate on vocabulary lessons longer when } \\
\text { my teacher uses the Interactive Whiteboard. }\end{array}$ & $\begin{array}{l}\mathrm{P} \\
(\%)\end{array}$ & 0.0 & 0.0 & 0.0 & 50.0 & 50.0 & 4.50 & 0.506 \\
\hline BA14 & $\begin{array}{l}\text { I prefer my teacher to use the Interactive } \\
\text { Whiteboard more frequently in vocabulary lessons. }\end{array}$ & $\begin{array}{l}\mathrm{P} \\
(\%)\end{array}$ & 5.0 & 5.0 & 5.0 & 35.0 & 50.0 & 4.20 & 1.091 \\
\hline
\end{tabular}

(*) SD: Strongly disagree, D: Disagree, U: Uncertain, A: Agree, SA: Strongly agree

From Table 18, all of the respondents revealed their longer concentration level on the vocabulary lessons with the aid of the Interactive Whiteboard (Item BA13, 50.0\% agree, 50.0\% strongly agree, $\mathrm{M}=4.50$, S.D. $=0.506$ ). Interestingly, $85.0 \%$ of the surveyed students did prefer their teachers to use this advanced tool more frequently in their vocabulary lessons (Item BA14, 35.0\% agree, 50.0\% strongly agree, $\mathrm{M}=4.20$, S.D. $=1.091$ ). Likewise, approximately $90.0 \%$ of the respondents wanted to participate actively in vocabulary lessons with the presence of the Interactive Whiteboard (Item BA11, $30.0 \%$ agree, $55.0 \%$ strongly agree, $M=4.18$, S.D. $=1.238$ ). Lastly, with Item BA12, three quarters of the participants expected to practice vocabulary tasks much more in case they were exposed to the Interactive Whiteboard (37.5\% agree, 37.5\% strongly agree, $\mathrm{M}=3.98$, S.D. $=1.131$ ).

\section{DISCUSSION}

\section{Research Question 1: Vocabulary Achievement, Vocabulary Retention}

As reviewed earlier, the Interactive Whiteboard contributed to the development of vocabulary mastery of young learners. With the educational aims of improving English vocabulary teaching and learning quality at the primary school context where the students are young learners, the researchers conducted study about the effects of the Interactive Whiteboard on the fifth-grade students' vocabulary learning at Tran Quang Khai primary school. The first research question, in association with the fifth-grade students' vocabulary achievement and vocabulary retention after the treatment of the Interactive Whiteboard activities, had its answer based on the analysis and interpretation of the vocabulary tests. Generally speaking, the results emerged from the analysis and interpretation process above revealed that the Interactive Whiteboard positively contributed to the young students' learning outcomes, i.e. 
vocabulary achievement and vocabulary retention. This finding was in harmony with that of the previous studies like Tate (2004), Hodge and Anderson (2007), Biro (2011), Katwibun (2014). That is to say, Research Hypothesis 1 was satisfied.

At the beginning of the study, both the control and the experimental groups had the resemblance in their vocabulary proficiency background. This was considered as a good condition, making the researchers confident of appraising the effectiveness of the Interactive Whiteboard. Following that, the Interactive Whiteboard activities were applied to the experimental group, while the conventional methods were still used for the control group. Specifically, the control group was treated with an emphasis of completing all the vocabulary activities available in the textbook, Family and Friends Grade 5 Special Edition. In contrast, to the experimental group, many Interactive Whiteboard activities such as Spotting the Errors, Matching Spelling and Sound (Bingo), Labeling Pictures, Ordering the Jumbled Sentences, Word Association and Free Writing were infused into the vocabulary lessons. To accomplish these activities, the students of the experimental group manipulated typical functions of the Interactive Whiteboard such as Drag and Drop, Hide and Reveal, and Color and Highlight.

At the tenth week of the study, the post-test was delivered to both groups to scrutinize if they made any progress in their vocabulary achievement. In regard to mean scores, both the control and the experimental groups improved their vocabulary achievement; however, the experimental group outperformed the control group in the post-test. In reference with paired samples t-test results, there was a statistically significant difference only found in the experimental group when the researchers made a comparison between the pre-test and the post-test results within groups. It seemed to be true that the Interactive Whiteboard benefited the students much in their vocabulary achievement.

Two weeks later, at the end of the study, the delayed post-test was sent to both groups to check whether the students retained the learnt words successfully. By means of paired samples t-tests, the two groups proved their good vocabulary retention after the two given weeks. Nevertheless, through the independent samples t-test, a statistically significant difference in the delayed post-test scores was ultimately between the control and the experimental groups. To conclude, the Interactive Whiteboard, a modern technology tool, really made the young students memorize the vocabulary more effectively for a period of time. Specifically, these students could memorize the word spellings, meanings and use better since they were much exposed to the practice and production activities for several times.

The effectiveness of the Interactive Whiteboard on the students' vocabulary achievement and retention could be elucidated by three prominent reasons. Firstly, the vocabulary lesson plans were prepared carefully regarding the quantity of vocabulary items, the task instructions, and the interactional patterns. In reality, in each lesson, only seven to ten new vocabulary items were taught. Secondly, the researchers were sufficiently trained on the use of the Interactive Whiteboard functions and the Interactive Whiteboard activities by the Ho Chi Minh City Department of Education and Training in Vietnam. Thirdly, the students were interested and motivated with the presence of the Interactive Whiteboard, making a positive contribution to their vocabulary achievement and vocabulary retention. Indeed, the students of the experimental group appeared to be active in their learning process with the aid of the Interactive Whiteboard. They participated in different vocabulary activities mediated by the Interactive Whiteboard during the lessons. They worked with their groups or their partners. To sum, the application of the Interactive Whiteboard should be continued with the next classes.

\section{Research Question 2: Learning Attitudes}

The second research question, in conjunction with the fifth-grade students' attitudes after the treatment of the Interactive Whiteboard in the vocabulary lessons, also was answered based on the questionnaire results which have just been interpreted above. Generally speaking, the fifth-grade students' positive learning attitudes towards the value of the Interactive Whiteboard to their vocabulary acquisition were 
spotted in this study. This finding was in harmony with that of the previous research bodies such as Tate (2004), Hodge and Anderson (2007), Biro (2011), Katwibun (2014), and Mai (2018). Accordingly, Research Hypothesis 2 was proven positively.

In respect of affective attitudes, most of the students felt motivated to learning English vocabulary items via the Interactive Whiteboard as they found the vocabulary lessons interesting. Theoretically, young learners, the fifth-grade students in this case, take great pleasure in what they do and say (Halliwell, 1992), are curious, imaginative, and playful by listening, imitating, watching, and doing things (Slattery \& Willis, 2001). In reality, the students had many chances to use this advanced tool for certain learning activities. In this study, they took part in various vocabulary activities such as Spotting the errors, Matching spelling and sound, Labeling pictures, Word association, Ordering the jumbled sentences, and Free Writing. To complete these vocabulary activities, the students were exposed to different Interactive Whiteboard functions, including Dragging and dropping, Hiding and revealing, Coloring and highlighting, etc. Indeed, these functions were hugely attractive to the fifth-grade students. In other words, the young students' degree of excitement and interest was significantly upgraded since the students experienced manipulating interactive functions of the Interactive Whiteboard. This was in harmony with the characteristics of young learners who love technological devices and want to learn with the support of modern technological equipment like the Interactive Whiteboard (Betcher \& Lee, 2009, as cited in Mai, 2018). More scrupulously, the majority of the participants found the difference between the use of blackboard and that of the Interactive Whiteboard by their English teacher. Clearly, the students became more excited and interested when their teacher integrated the Interactive Whiteboard into the vocabulary lessons.

In regard to cognitive attitudes, most of the fifth-grade students strongly believed in the usefulness of the Interactive Whiteboard to their vocabulary achievement. More specifically, they positively thought that they could remember word forms longer, understand word meanings better, grasp word use more easily, and pronounce words more correctly. Academically, when teaching any word to the students, the teachers should exploit its varied aspects such as pronunciation, spelling, meaning and use (Nation, 2001). It is clear that based on the quantitative findings, the mediation of the Interactive Whiteboard became a fruitful way to help the students to grasp the vocabulary knowledge on different angles. In this research, the Interactive Whiteboard was used in different stages of a vocabulary lesson such as Presentation, Practice, Production and Review. For example, the researcher utilized visual aids from the Interactive Whiteboard to introduce new words, and then moved to implement a few game-like activities for the students to practice and recycle the newly learnt words. When these students have much more chances to be exposed to the new items, they can use and memorize vocabulary more effectively and longer (Wallace, 1982). To sum up, the Interactive Whiteboard activities could actually facilitate the fifth-grade students' vocabulary noticing, retrieval and creative use. Therefore, it might be effective in case the primary school teachers took advantage of the Interactive Whiteboard to design interactive vocabulary activities, serving for their lesson's strings.

With reference to behavioral attitudes, the majority of the participants exhibited their tendencies of actions positively. The first positive tendency was that with the Interactive Whiteboard, they wanted to take part in vocabulary lessons collaboratively with their classmates. In principle, the use of the Interactive Whiteboard has the potential to increase interaction among students themselves in the classroom (Shen \& Chuang, 2009). In this experiment, the vocabulary activities used with Interactive Whiteboard were highly interactive where the students were required to study collectively with their friends. The second positive tendency was that the students wanted to practice more vocabulary tasks with the aid of the Interactive Whiteboard. It could be concluded that vocabulary tasks or activities that the researchers designed with the Interactive Whiteboard drew much attention to the students owing to their attractiveness and usefulness. The third positive tendency was that an overwhelming number of the students seemed to concentrate longer on the vocabulary lessons with the presence of 
the Interactive Whiteboard. It is conceded that the Interactive Whiteboard is especially effective in expanding students' attention (Farrar, 2014). In reality, the Interactive Whiteboard is very similar to a chalkboard, but it involves colors, images, sounds and even moving images, which can capture the students' engagement. In addition, children have a very short attention span, losing their interest after ten minutes by dint of less attractive activities (Harmer, 2001). Strikingly, the Interactive Whiteboard could increase the students' level of concentration and engagement.

\section{CONCLUSION AND RECOMMENDATIONS}

Based on the results from the pre-test, post-test and delayed post-test, it might be concluded that the Interactive Whiteboard activities actually made a great contribution to the fifth-grade students' vocabulary achievement and vocabulary retention ability in terms of word form, word meaning and word use. In addition, through the results from the questionnaire, the Interactive Whiteboard activities were found to enhance the fifth-grade students' motivation, interest, and engagement level into their vocabulary acquisition.

To terminate the paper, some recommendations are made for both language teachers and school administrators. Firstly, teachers are encouraged to devise the vocabulary lessons within the inclusion of the Interactive Whiteboard activities heedfully so that these activities not only provoke young learners' motivation, but also improve their target learning output (e.g. vocabulary achievement, retention) as expected. To fulfill it, teachers need to furnish themselves with adequate knowledge of vocabulary activities and the Interactive Whiteboard functions and renew their instructional approaches and methods flexibly as well. Secondly, it seems true that many fifth-grade students would rather manipulate the Interactive Whiteboard functions than participate in vocabulary learning. They may make noise while moving and doing the Interactive Whiteboard manipulation. Hence, teachers should set out strict disciplines and identify clear objectives prior to enacting the Interactive Whiteboard vocabulary activities. Thirdly, as increasing demand for the utilization of technology in educational settings, along with the potential benefits of the Interactive Whiteboard proven in this study, administrators should decide to equip at least one Interactive Whiteboard for their primary schools.

\section{REFERENCES}

Beeland, W. D. (2002). Student engagement, visual learning, and technology: Can interactive whiteboards help? Annual Conference of the Association of Information Technology for Teaching Education. Dublin, Ireland: Trinity College.

Biro, P. (2011). Students and Interactive Whiteboard. Acta Didactica Napocensia, 4(2-3), 29-38.

Cohen, L., Manion, L., \& Morrison, K. (2011). Research methods in education. NY: Routledge.

Creswell, J. W. (2012). Educational research: Planning, conducting, and evaluating quantitative. Boston: Pearson.

Daniels, H., \& Zemelman, S. (2004). Subjects matter: Every teacher's guide to content-area reading. Portsmouth, NH: Heinemann.

Farrar, R. S. A. (2004). The effectiveness of using smart boards in developing tenth graders' vocabulary achievement, retention, and attitudes towards English in Gaza (Unpublished master thesis). The Islamic University, Gaza.

Halliwell, S. (1992). Teaching English in the Primary Classroom. Harlow: Longman.

Harmer, J. (2001). The practice of English language teaching. Essex, England: Longman.

Hodge, S., \& Anderson, B. (2007). Teaching and learning with an Interactive White Board: A teacher's journey. Learning, Media, and Technology, 32(3), 271-282. 
Kara, A. (2009). The Effect of a 'Learning Theories' unit on students' attitudes towards learning. Australian Journal of Teacher Education, 34(3), 100-113.

Katwibun, H. (2014). Using an Interactive Whiteboard in vocabulary teaching. Procedia-Social and Behavioral Sciences, 116, 674-678.

Khoo, E., Merry, R., Nguyen, N. H., Bennett, T., \& MacMillan, N. (2014). Early childhood education teachers' iPad supported practices in young children's learning and exploration. Computers in New Zealand Schools: Learning, Teaching, Technology, 25(1/3), 3-20.

Koshy, V. (2005). Action research for Improving practice: A practical guide. London: PCP/Sage.

Luu, T. T. (2012). Vocabulary recollection through games. Theo. \& Pra. to Lang. Stu., 2(2), 257-264.

Mai, T. N. H. (2018). Teachers' and fifth graders' attitudes toward the use of Interactive Whiteboards at Le Thi Hong Gam primary school in EFL vocabulary teaching and learning (Unpublished master thesis). Vietnam: Ho Chi Minh City Open University.

Nation, P. (2001). Learning vocabulary in another language. New York: Cambridge University Press.

Nguyen, T. T. T. (2015). Information and Communication Technology (ICT) and teaching English in rural Vietnamese primary schools: Policies, practices, and implementation factors (Unpublished doctoral thesis).

Nguyen, T. T. H. \& Khuat, T. T. N. (2003). Learning vocabulary through games. Asian EFL Journal. http://www.asian-efljournal.com/ dec-03-sub.Vn.php.

Nguyen, T. G-T., \& Tran, Q. T. (2015). The Use of English Vocabulary Learning Strategies among Vietnamese High School Students. Conference proceedings 2018, 223-232.

Pallant, J. (2005). SPSS survival guide: A step by step guide to data analysis using SPSS for windows. (3rd ed.). New York: Open University Press.

Prensky, M. (2010). Teaching digital natives: Partnering for real learning. Thousand Oaks: Sage.

Richard, J. C \& Renandya, W. A. (2002). Methodology in language teaching: An anthology of current practice. Cambridge: Cambridge University Press.

Schmitt, N. (2008). Review article: Instructed second language vocabulary learning. Language Teaching Research, 12, 329-363.

Shen, C-C., \& Chuang, H-M. (2009). An Investigation on user communication behaviour in an Interactive Whiteboard technology environment. WSEAS Transactions on Comm., 8, 184-195.

Slattery, M. \& Willis, J. (2001). English for primary teachers. Oxford: Oxford University Press.

Tate, L. (2004). Using interactive whiteboard to increase student retention, attention, participation, interest, and success in a required general education college. Retrieved from http://www.smarterkids.org/research/pdf/tate.pdf.

Wallace, M. (1982). Teaching vocabulary. London: Heinemann Educational Books. 